http://ejournal.upi.edu/index.php/jaz - e-mail: jurnal.zonasi@gmail.com dan jurnal_zonasi@upi.edu doi.org/10.17509/jaz.v3i1.21737

\title{
PENGELOLAAN SAMPAH DENGAN PENDEKATAN BEHAVIOR MAPPING DI PASAR TRADISIONAL KOTA TASIKMALAYA
}

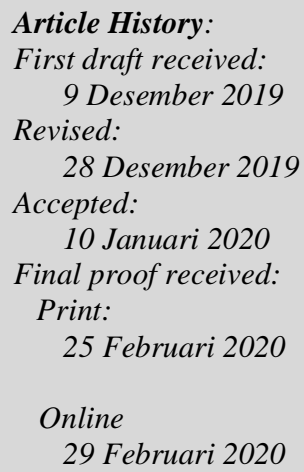

\author{
Dicky Nurmayadi ${ }^{1}$; Agi Rivi Hendardi ${ }^{2}$ \\ 1,2, Universitas Perjuangan, Tasikmalaya, Indonesia \\ Jl. Pembela Tanah Air (PETA) No. 177, Kahuripan, Kec. Tawang, Kota Tasikmalaya \\ Email: dickynurmayadi@unper.ac.id \\ agirivihendardi@unper.ac.id
}

\begin{abstract}
Traditional markets are identical with dirty, seedy, and smelly due to waste problems generated by the activities / processes of the market itself. The market has a big enough role to fulfill daily needs and support the economy of the urbans. The City of Tasikmalaya has several traditional markets that are provided to meet the daily needs of its people, local governments with various funding programs has to build or revitalize markets with the hope that they can provide more services for its users. The development and revitalization process that is carried out is sometimes only focused to the physical aspects without thinking about the environmental management system, especially on the problem of waste management systems that involve the behavior and activities of market users. This study was conducted to obtain a description of the condition of waste management in traditional markets in the City of Tasikmalaya through an approach to the activities and behavior of users, management institutions, and facilities in the market environment using the Behavior Mapping method. From the research results obtained data that almost all existing markets do not yet have a suitable waste management system, garbage is only collected without going through a good sorting process, users are not too concerned with the conditions of existing waste problems, the existing institutions also have not been maximally managed, the facilities provided are only in the form of temporary waste collection facilities and the conditions can be seen from the condition.
\end{abstract}

Keywords: Waste, Traditional Markets, Management System, Behavior Mapping

Abstrak: Pasar tradisional identik dengan kotor, kumuh, dan bau akibat permasalahan sampah yang dihasilkan oleh aktivitas/proses kegiatan dari pasar itu sendiri. Pasar memiliki peran yang cukup besar bagi pemenuhan kebutuhan sehari-hari dan penunjang perekonomian masyarakat di perkotaan. Kota Tasikmalaya memiliki beberapa pasar tradisional yang disediakan untuk memenuhi kebutuhan sehari-hari masyarakatnya, pemerintah daerah dengan berbagai program pendanaan membangun atau merevitalisasi pasar dengan harapan agar dapat memberikan pelayanan yang lebih bagi penggunanya. Proses pembangunan dan revitalisasi yang dilakukan terkadang hanya terfokus kepada aspek fisik tanpa memikirkan sistem pengelolaan lingkungan khususnya pada masalah system pengelolaan sampah yang melibatkan perilaku dan aktivitas dari pengguna pasar. Penelitian ini dilakukan untuk memperoleh gambaran bagaimana kondisi pengelolaan sampah di pasar tradisional di Kota Tasikmalaya melalui pendekatan terhadap aktivitas dan perilaku pengguna, lembaga pengelola, dan fasilitas yang ada di lingkungan pasar menggunakan metode Behavior Mapping. Dari hasil penelitian diperoleh data bahwa hampir semua pasar yang ada belum memiliki system pengelolaan sampah yang sesuai, sampah hanya dikumpulkan tanpa melalui proses pemilahan yang baik, pengguna tidak terlalu peduli dengan kondisi permasalahan sampah yang ada, kelembagaan yang ada juga belum secara maksimal melakukan pengelolaan, fasilitas yang disediakan hanya berupa sarana penampungan sampah sementara dan dilihat dari kondisinya pun terkesan asal ada.

Kata Kunci: Sampah, Pasar Tradisional, Pengelolaan, Behavior Mapping 


\section{Pendahuluan}

Keberadaan sampah sampai saat ini masih menjadi permasalahan yang melanda hampir di seluruh wilayah di Indonesia. Berbagai program dan strategi dilakukan pemerintah baik pusat maupun daerah untuk mengatasi berbagai permasalahan yang ditimbulkan oleh sampah, khususnya dalam hal pengelolaan. Pengelolaan sampah merupakan tanggung jawab pemerintah sebagai salah satu bentuk pelayanan publik, yaitu dengan membuat kebijakan dalam pengelolaan sampah (Mulasari, Husodo, \& Muhadjir, 2016).

Sampah sendiri adalah materi yang karena memiliki nilai yang kurang menguntungkan baik secara ekonomi maupun lingkungan akhirnya dibuang. Kuantitas sampah yang terdapat di lingkungan perkotaan setiap tahun terus meningkat seiring dengan pertambahan jumlah penduduk serta kualitas kehidupan masyarakat itu sendiri yang cenderung lebih konsumtif. Terdapat korelasi yang erat dalam permasalahan sampah antara pola hidup dengan budaya masyarakat itu sendiri (Sahil, et.al. 2016). Pertambahan jumlah penduduk dan perubahan pola konsumsi masyarakat menimbulkan bertambahnya volume, jenis dan karakteristik sampah yang semakin beragam (Sidik, 2011). Cara pandang masyarakat pada sampah seharusnya tidak lagi memandang sampah sebagai hasil buangan yang tidak berguna. Sampah seharusnya dipandang sebagai sesuatu yang mempunyai nilai guna dan manfaat (Asteria \& Heruman, 2016).

Keberadaan pasar tradisional (Hantono, Butudoka, Prakoso, dan Yulisaksono, 2019) merupakan penopang perekonomian dan keberlangsungan hidup bagi sebagian besar masyarakat di daerah, meskipun dalam aktivitas yang terjadi pasar menyumbang berbagai jenis sampah dalam volume yang cukup besar. Pasar tradisional memiliki stigma yang buruk dalam hal pengelolaan lingkungan, pasar tradisional selalu identik dengan kesan kotor, kumuh, dan bau. Kondisi kebersihan yang buruk dan terkesan kumuh menjadi salah satu alasan banyak beralihnya pengunjung pasar tradisional ke pasar modern (Andriani \& Ali, 2013). Khusus dari pasar tradisional, banyak dihasilkan sisa sayur, buah, makanan yang mudah membusuk. Secara umum sampah dari sumber ini adalah mirip dengan sampah domestik tetapi dengan komposisi yang berbeda (Damanhuri \& Padmi, 2011), Pasar merupakan salah satu bagian penting dalam proses penyehatan lingkungan (Yaqin, 2019).

Kota Tasikmalaya sebagai salah satu kota perdagangan di Jawa Barat memiliki beberapa pasar tradisional yang memiliki peran penting bagi perkembangan perekonomian masyarakat, yaitu: a). Pasar Cikurubuk, b). Pasar Pancasila, c). Pasar Indihiang, d). Pasar Padayungan, e). Pasar Cibeuti, f). Pasar Gegernoong, g) Pasar Burung Besi, dan h) Pasar Nyemplong/Sindang hayu.

Tujuan dari dilakukannya kajian terhadap pengembangan pengelolaan sampah dan limbah pasar tradisional di Kota Tasikmalaya adalah dapat diperolehnya kriteria-kriteria teknis yang dapat digunakan sebagai pendukung dalam proses perencanaan maupun pengembangan model pasar tradisional khususnya untuk mengurangi dampak negatif dari sampah yang dihasilkan dari berbagai aktivitas pengguna.

\section{Metode Penelitian}

Pelaksanaan penelitian ini dimulai dengan penentuan objek penelitian dan kemudian dilanjutkan dengan analisis terhadap kondisi dan teknis pengelolaan sampah di objek terpilih. Pengelompokkan dan penentuan objek penelitian dilakukan dengan mengacu kepada standar/keriteria yang ada kemudian dilakukan analisis menggunakan metode kuantitatif. Setelah objek penelitian diperoleh, tahap selanjutnya adalah melakukan pengamatan lebih spesifik terhadap pengelolaan sampah yang ada dengan pendekatan terhadap aktivitas pengguna menggunakan metode deskriptif kuantitatif.

Populasi yang menjadi objek dalam penelitian ini adalah pengguna pasar dan pembuat kebijakan dalam pengelolaan sampah pasar di Kota Tasikmalaya. Adapun untuk teknik pengumpulan data menggunakan metode pengamatan dan wawanacara/interview yang meliputi beberapa tahapan diantaranya, yaitu :

1. Identifikasi variabel yang akan digunakan dimana merupakan penjabaran dari konsep pendekatan behavior mapping,

2. Melakukan pembobotan (level urgensi) untuk masing-masing variabel,

3. Melakukan assessment terhadap variabel penting yang berpengaruh terhadap pengelolaan sampah di lingkungan pasar Kota Tasikmalaya.

\section{Hasil dan Pembahasan}

\subsection{Pasar Tradisional di Kota Tasikmalaya}

Pasar tradisional merupakan sebuah ruang social di area perkotaan yang masih cukup terasa bagaimana kental/sarat akan realisasi proses interaksi antara penjual dan pembeli. Pasar tradisional perlu dijaga untuk membentuk karakter kota yang arif, humanis, dan santun (Ibrahim, 2018). Citra buruk sebuah pasar tradisional 
yang ditimbulkan oleh sampah menjadi factor yang membuat pengguna khususnya pembeli tidak nyaman saat berada di lingkungan pasar.

Keberadaan pasar tradisional masih dibutuhkan keberadaannya oleh masyarakat meski kepopuleran khususnya dikalangan generasi muda mulai tergantikan oleh keberadaan pasar-pasar modern yang banyak dibangun di lingkungan perkotaan. Diperlukan strategi dan perencanaan yang lebih matang untuk mengembangkan pasar tradisional agar keberadaanya tetap menjadi salah satu daya dukung perekonomian masyarakat. Menurut Giantari (2018), terdapat dua langkah yang bisa dilakukan untuk mengambangkan pasar tradisional, yaitu renovasi dan revitalisasi. Renovasi merupakan kegiatan yang berkaitan dengan peningkatan kualitas fisik bangunan, sementara revitalisasi adalah konseptualisasi ulang sistem bangunan, baik secara internal maupun eksternal.

Kota Tasikmalaya yang secara geografis berada di jalur yang sangat strategis menghubungkan Ibu Kota Provinsi dengan wilayah Priangan Timur maupun Jawa Tengah dimana memiliki andil yang cukup besar dalam pengembangan perekonomian khususnya di wilayah Jawa Barat. Untuk memenuhi kebutuhan masyarakat 10 kecamatan dan terdiri dari 69 kelurahan, Kota Tasikmalaya memiliki beberapa pasar yang dalam kegiatannya menyediakan keperluan bagi kebutuhan sehari-hari.

Tabel 1. Pasar di Kota Tasikmalaya

\begin{tabular}{|c|c|c|c|c|c|c|}
\hline No & Nama Pasar & Alamat & $\begin{array}{c}\text { Tahun } \\
\text { Dibangun }\end{array}$ & $\begin{array}{c}\text { Luas } \\
\text { Tanah (m2) }\end{array}$ & $\begin{array}{c}\text { Luas } \\
\text { Bangunan } \\
(\mathbf{m} 2)\end{array}$ & $\begin{array}{c}\text { Jumlah } \\
\text { Kios } \\
\text { (unit) }\end{array}$ \\
\hline 1 & Cikurubuk & $\begin{array}{l}\text { Jl. Residen } \\
\text { Ardiwinangun, Kel. } \\
\text { Linggajaya Kec. } \\
\text { Mangkubumi }\end{array}$ & 1994 & 43.120 & 25.650 & 2.772 \\
\hline 2 & Pancasila & $\begin{array}{l}\text { Jl. Pancasila, Kel. } \\
\text { Lengkongsari, Kec. } \\
\text { Tawang }\end{array}$ & 1995 & 6.500 & 4.656 & 299 \\
\hline 3 & Indihiang & $\begin{array}{l}\text { J1. Letnan Harun, } \\
\text { Kel. Sukamaju Kaler, } \\
\text { Kec. Indihiang }\end{array}$ & 1997 & 10.622 & 743 & 402 \\
\hline 4 & Padayungan & $\begin{array}{l}\text { Jl. Perintis } \\
\text { Kemerdekaan, Kel. } \\
\text { Tugujaya, Kec. } \\
\text { Cihideung }\end{array}$ & 1995 & 9.000 & 1.968 & 261 \\
\hline 5 & Cibeuti & $\begin{array}{l}\text { J1. Raya Cibeuti, Kel. } \\
\text { Cibeuti, Kec. Kawalu }\end{array}$ & 1990 & 696 & 691 & 28 \\
\hline 6 & Gegernoong & $\begin{array}{l}\text { J1. Tamansari, Kel. } \\
\text { Tamanjaya, Kec. } \\
\text { Tamansari }\end{array}$ & 1999 & 1.000 & 538 & 91 \\
\hline 7 & $\begin{array}{l}\text { Burung dan } \\
\text { besi }\end{array}$ & $\begin{array}{l}\text { Jl. KH. EZ Mutaqin, } \\
\text { Kel. Linggajaya, } \\
\text { Kec. Mangkubumi }\end{array}$ & 1997 & 6.407 & 444 & 244 \\
\hline 8 & $\begin{array}{l}\text { Nyemplong/ } \\
\text { Sindanghayu }\end{array}$ & $\begin{array}{l}\text { Setiawargi, Kel. } \\
\text { Setiawargi, Kec. } \\
\text { Tamansari }\end{array}$ & 2016 & 5.650 & 1.364 & 26 \\
\hline
\end{tabular}

Sumber : https://portal.tasikmalayakota.go.id/sarana-dan-prasarana/tempat-belanja/pasar-tradisional/

\subsection{Sistem Pengelolaan Sampah di Pasar Tradisional}

Masalah akan keberadaan sampah merupakan sebuah problematika yang sampai saat ini belum selesai dihadapi oleh kota-kota diIndonesia. Volume timbulan sampah yang terus bertambah memiliki tendensi terkait dengan pertambahan jumlah penduduk (Sahwan, 2012). Pengelolaan sampah perkotaan yang buruk di negara berkembang adalah ancaman besar bagi kesehatan masyarakat dan kualitas lingkungan serta dapat mengurangi kualitas kehidupan masyarakat (Opara, 2016). Ancaman terhadap lingkungan dan kesehatan akibat sampah merupakan beban yang harus ditanggung oleh seluruh kota di seluruh dunia (Neriamparampil, 2018).

Menurut data dari World Bank (2012) disebutkan bahwa negara-negara berkembang diperkirakan menghabiskan 50\% dari anggaran yang dimiliki untuk mengelola permasalahan sampah dan limbah. Manajemen pengelolaan limbah yang tidak tepat dapat mengakibatkan masalah kesehatan dan lingkungan yang cukup serius (Yang, 2018). 
Prinsip utama bagi setiap negara terkait pengelolaan limbah dan sampah adalah pencegahan, prinsip kedua adalah daur ulang (recycle) dan produksi energy (energy production), dan prinsip terakhir yaitu pembuangan limbah tanpa daur ulang dan menghasilkan energy (Zaman, et.al., 2017).

Kondisi lingkungan pasar khususnya pasar tradisional memiliki image lingkungan yang kotor, kumuh, dan bau. Tanatangan yang dihadapi pasar tradisional saat ini adalah bagaimana lingkungan pasar tersebut harus sehat dan bersih dengan pengelolaan seperti pasar modern (Sulistyo \& Cahyono, 2010), kondisi lingkungan pasar tradisional yang memiliki kesan kotor dan kumuh tersebut dihasilkan dari sampah khususnya jenis organik. Sampah yang dihasilkan dari pasar tradisional memiliki karakteristik yang berbeda dengan sampah dari perumahan yang apabila dilihat dari komposisinya lebih dominan sampah organik (Arifin, 2018). Sampah organik sendiri merupakan faktor utama yang berpengaruh terhadap kualitas emisi gas dari tempat-tempat pembuangan sampah karena mengandung karbon organik yang mudah terurai (Wahyono, 2015).

\subsection{Behavior Mapping Pengguna Pasar}

Dengan pemetaan dan setting perilaku pengguna (Behavior Mapping) membuat sebuah desain arsitektur dapat diadaptasikan, fleksibel atau terbuka (Laurens, 2007). Pasar tradisional perlu tetap eksis dan bersaing dengan pasar-pasar modern yang banyak bermunculan di kawasan perkotaan sehingga perlu adanya revitalisasi, yang mana menurut Proshanky (1976), proses renovasi dan revitalisasi dapat dilakukan dengan metode pendekatan behavior mapping untuk menganalisa data dan fakta yang terjadi di lapangan melalui pemetaan perilaku.

Proses pendekatan pemetaan perilaku dilakukan berdasarkan:

1. Person-Center Maps,

Metode ini fokus pada bagaimana pengamatan terhadap pergerakan manusia di periode waktu tertentu, (Menggambarkan konfigurasi dan penzoningan kawasan pasar yang ada saat ini berkaitan dengan permasalahan sampah).

Pasar pada umumnya dibuat blok/zoning sesuai dengan komoditas barang/jasa yang dijual, mulai dari sayuran, buah-buahan, makanan ringan, perlengkapan rumah tangga, pakaian jadi, hingga hewan ternak. Masing-masing blok yang ada memiliki potensi timbulan sampah yang berbeda sesuai dengan komoditas barang yang dijual.

Tabel 2. Zoning Pasar dan Potensi Timbulan Sampah

\begin{tabular}{|c|c|c|c|}
\hline No & $\begin{array}{c}\text { Kelompok Zoning } \\
\text { Pasar }\end{array}$ & Komoditas Barang/Jasa & $\begin{array}{l}\text { Potensi Sampah } \\
\text { yang Dihasilkan }\end{array}$ \\
\hline 1 & Area Basah & $\begin{array}{ll}\text { - } & \text { Sayur-mayur } \\
\text { - } & \text { Buah-buahan, } \\
\text { - } & \text { Ikan dan daging, } \\
\text { - } & \text { Makanan, } \\
\text { - } & \text { Ternak }\end{array}$ & $\begin{array}{l}\text { - } \quad \text { Sayuran dan buah } \\
\text { busuk, } \\
\text { - } \quad \text { Kotoran ikan dan } \\
\text { ayam, } \\
\text { - } \quad \text { Darah, } \\
\text { - } \quad \text { Sisa makanan, } \\
\text { - } \quad \text { Air sabun bekas } \\
\text { - } \\
\text { cucian piring, } \\
\text { Kotoran ternak. }\end{array}$ \\
\hline 2 & Area Kering & $\begin{array}{ll}\text { - } & \text { Pakaian, } \\
\text { - } & \text { Sepatu dan sandal, } \\
\text { - } & \text { Sembako, } \\
\text { - } & \text { Perlengkapan rumah } \\
& \text { tangga, } \\
\text { - } & \text { Perhiasan, }\end{array}$ & $\begin{array}{l}\text { - Plastik makanan, } \\
\text { - Sterofoam, } \\
\text { - } \quad \text { Botol minuman, }\end{array}$ \\
\hline 3 & Area service/pelayanan & $\begin{array}{ll}\text { - } & \text { Kantor pengelola, } \\
\text { - } & \text { Area parkir, } \\
\text { - } & \text { Toilet, } \\
\text { - } & \text { Musholla, } \\
\text { - } & \text { Tempat penampungan } \\
& \text { sampah, } \\
\text { - } & \text { Pos pengamanan, } \\
\text { - } & \text { Taman/area terbuka hijau, }\end{array}$ & $\begin{array}{ll}\text { - } & \text { Bungkus } \\
\text { makanan, } \\
\text { - } & \text { Puntung rokok, } \\
\text { - } & \text { Plastik dan botol } \\
& \text { air mineral, }\end{array}$ \\
\hline
\end{tabular}

Sumber: Survei 2019 
2. Place-Centered Maps,

Pada bagian ini fokus terhadap bagaimana pengguna mengatur dirinya dalam sebuah lokasi, (cara berkomunikasi dan berinteraksi, jam efektif terjadinya proses timbulan sampah, serta aktifitas yang terindikasi akan memberikan dampak bagi timbulan sampah).

Pengelompokkan peran pengguna di lingkungan pasar disesuaikan dengan kelompok aktifitas yang terjadi, mulai dari pedagang, pembeli, pengelola, dan pendukung.

Tabel 3. Kelompok dan Aktifitas Pengguna Pasar

\begin{tabular}{|c|c|c|}
\hline No & Kelompok Pengguna & Aktifitas yang Terjadi \\
\hline 1 & Pedagang & $\begin{array}{ll}\text { - } & \text { Mempersiapkan barang dagangan, } \\
\text { - } & \text { Menunggu dan melayani pembeli, } \\
\text { - } & \text { Memilah dan mengatur barang dagangan, } \\
\text { - } & \text { Mengobrol, } \\
\text { - } & \text { Merokok, } \\
\text { - } & \text { Makan, beristirahat, dan sholat }\end{array}$ \\
\hline 2 & Pembeli/pengunjung & $\begin{array}{ll}\text { - } & \text { Berjalan/berkeliling pasar, } \\
\text { - } & \text { Membeli dan menawar harga, } \\
\text { - } & \text { Istirahat (duduk,merokok, makan, dan ke } \\
\text { - } & \text { PC) } \\
\text { - } & \text { Menunir kendaraan, } \\
& \text { Mengu/duduk-duduk }\end{array}$ \\
\hline 3 & Pengelola & $\begin{array}{ll}\text { - } & \text { Memberikan informasi, } \\
\text { - } & \text { Mencatat, } \\
\text { - } & \text { Berkeliling pasar, } \\
\text { - } & \text { Menerima tamu, } \\
\text { - } & \text { Istirahat (duduk, makan, dan ke WC) }\end{array}$ \\
\hline 4 & Pendukung & $\begin{array}{ll}\text { - } & \text { Mengatur parkir, } \\
\text { - } & \text { Kuli angkut, } \\
\text { - } & \text { Petugas keamanan, } \\
\text { - } & \text { Petugas kebersihan. }\end{array}$ \\
\hline
\end{tabular}

Sumber: Survei 2019

3. Physycal Trace

Pendekatan yang dilakukan untuk memperoleh tanda-tanda yang ditinggalkan pengguna setelah terjadinya aktifitas. (posisi penempatan tempat sampah, ukuran luas penampungan sampah, dan dukungan sarana dan prasarana pengelolaan sampah dari kebijakan pengelola).

Kegiatan yang berlangsung di dalam pasar menghasilkan timbulan sampah yang tidak sedikit, bahkan di pasar Cikurubuk volume sampah setiap harinya diperkirakan mencapai $35 \mathrm{~m}^{3}$. Pasar pada umumnya tidak memiliki sistem pengolahan sampah yang memadai, pasar hanya memiliki sarana berupa lokasi penampungan sampah sementara sebelum pada akhirnya diangkut oleh pihak dinas Lingkungan Hidup ke tempat pembuangan akhir.

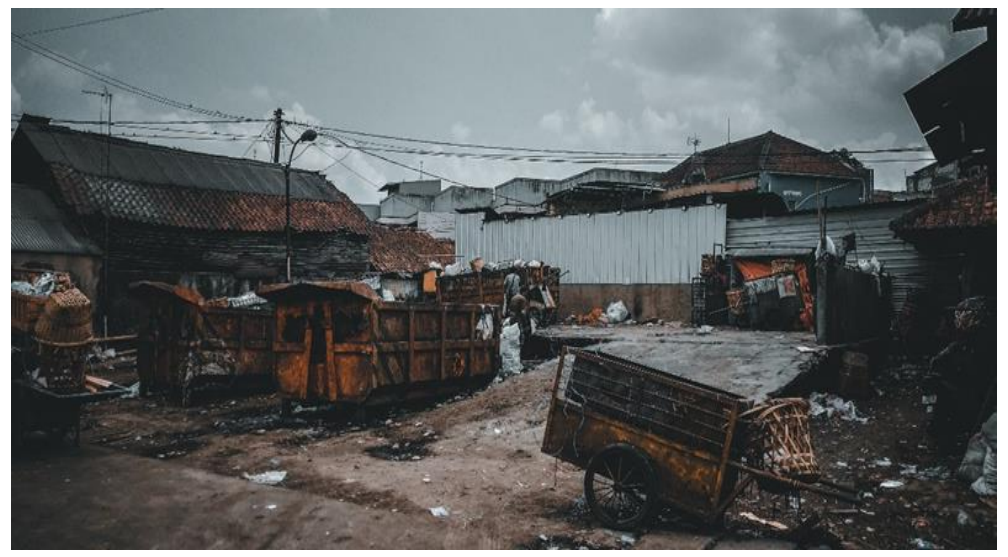

Gambar 1. Lokasi Penampungan Sampah di Pasar Cikurubuk Sumber: pengamatan, 2019 


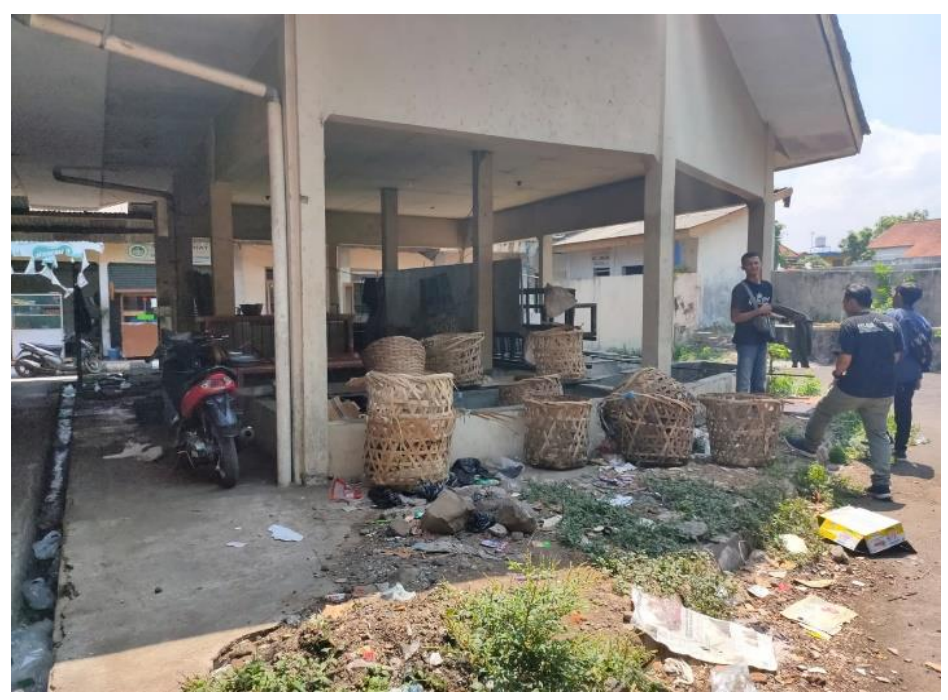

Gambar 2. Lokasi Penampungan Sampah di Pasar Padayungan Sumber: pengamatan, 2019

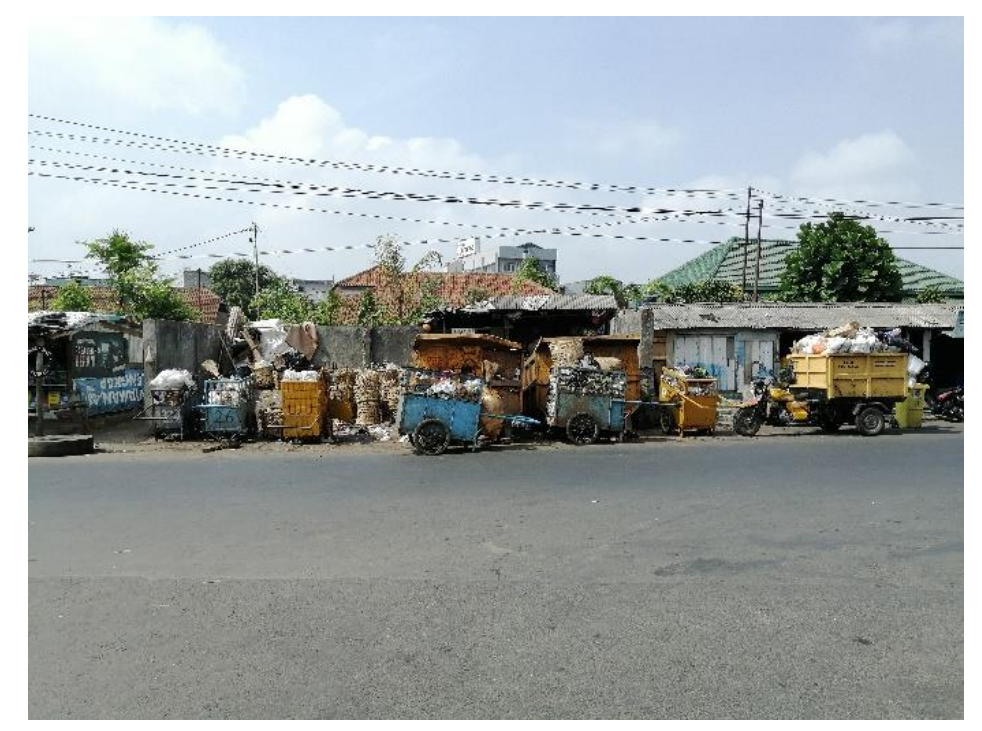

Gambar 3. Lokasi Penampungan Sampah di Pasar Pancasila Sumber: pengamatan, 2019

\section{Kesimpulan}

Kesimpulan dari penelitian ini adaah bagaimana pendekatan terhadap kegiatan dan aktivitas pengguna perlu menjadi salah satu perhatian dalam menentukan sistem pengelolaan sampah dan limbah di pasar tradisional. Kondisi pengelolaan dan penanganan sampah di beberapa pasar tradisional di Kota Tasikmalaya masih mengandalkan sistem pengangkutan dan penanganan dari pihak pemerintah daerah, pengguna sesuai aktivitas dan kegiatan yang dilakukan sesuai dengan pengamatan belum memberikan andil yang cukup besar dalam proses penanganan sampah dan limbah yang dihasilkan. Penataan zoning kawasan sesuai dengan komoditas barang dan jasa sudah diterapkan di pasar, akan tetapi belum ada kejelasan dalam penyusunan tata letak fasilitas penunjang untuk pembuangan dan pengolahan sampah.

Adapun saran yang dapat diberikan dari hasil penelitian ini adalah masih perlunya proses penelitian untuk mengembangkan system penampungan sampah di lingkungan pasar tradisional yang tepat baik dari fungsi, penempatan, dan desain visual sehingga tidak menggangu aktivitas dan lingkungan pasar yang ada. 


\section{Ucapan Terima Kasih}

Ucapan terimakasih kami sampaikan untu seluruh pihak yang telah membantu dalam kegiatan penelitian ini, khususnya kepada :

1. Rektor Universitas Perjuangan Tasikmalaya,

2. Ketua LP2M Universitas Perjuangan Tasikmalaya,

3. DPRM Dikti yang telah memberikan bantuan dana bagi kami untuk melaksanakan kegiatan skim Penelitian Dosen Pemula (PDP).

\section{Referensi}

Andriani, M. N., \& Ali, M. M. (2013). Kajian Eksistensi Pasar Tradisional Kota Surakarta. Jurnal Teknik Pwk, 2(2), 252-269. Retrieved from http://ejournal-s1.undip.ac.id/index.php/pwk

Arifin, H. (2018). Pengelolaan Sampah Pasar Kuraitaji Kecamatan Pariaman Selatan Kota Pariaman. Menara Ilmu, XII(8), 61-68. Retrieved from https://www.jurnal.umsb.ac.id/index.php/menarailmu/article/ download/867/778

Asteria, D., \& Heruman, H. (2016). Bank Sampah Sebagai Alternatif Strategi Pengelolaan Sampah Berbasis Masyarakat Di Tasikmalaya (Bank Sampah (Waste Banks) as an Alternative of Community-Based Waste Management Strategy in Tasikmalaya). Manusia Dan Lingkungan, 23(1), 136-141. Retrieved from https://journal.ugm.ac.id/JML/article/view/18783/12114

Damanhuri, E., \& Padmi, T. (2011). Pengelolaan sampah. institut Teknologi Bandung. Institut Teknologi Bandung.

Giantari, K., Surya,S., Ni Nyoman, K. Y., dan Ida Bagus, A. Y. (2018). Development and revitalization strategies for traditional markets in bali. International Journal of Social Economics, 45(7), 1058-1070. doi:http://dx.doi.org/10.1108/IJSE-09-2017-0414

Hantono, D., Butudoka, Z., Prakoso, A. A., dan Yulisaksono, D. (2019). Adaptasi Seting Ruang Pasar Jiung Terhadap Kehadiran Pasar Temporer Di Jalan Kemayoran Gempol Barat Jakarta. Jurnal Arsitektur ZONASI, 2(2), 75. https://doi.org/10.17509/jaz.v2i2.13628

Ibrahim, R.M., Mahendra, A.S. (2018). Arsitektur Pasar dan Manusia Sebagai Penggerak Peradaban Kota. Jurnal Sains dan Seni ITS, 7(2), G277-G283.

Laurens, Joyce Marcella. 2007. Arsitektur dan Perilaku Manusia. Jakarta: PT. Grasindo

Mulasari, A., Husodo, A. heru, \& Muhadjir, N. (2016). Analisis Situasi Permasalahan Sampah Kota Yogyakarta Dan Kebijakan Penanggulangannya. Jurnal Kesehatan Masyarakat, 11(2), 96-106. https://doi.org/http://dx.doi.org/10.15294/kemas.v11i1.3521

Sahwan, F. L. (2012). Potensi Sampah Kota Sebagai Bahan Baku Kompos Untuk Mendukung Kebutuhan Pupuk Organik Dalam Rangka Memperkuat Kemandirian Pangan. Jurnal Teknik Lingkungan, 13(2), 193-201. Retrieved from http://ejurnal.bppt.go.id/index.php/JTL/article/view/1418

Sidik, M. A. (2011). Peran adipura pada pelaksanaan sistem pengelolaan sampah di indonesia. Teknologi Lingkungan, 12(3), 319-331. Retrieved from http://ejurnal.bppt.go.id/index.php/JTL/article/view/ $1241 / 1050$

Neriamparampil, C. C. (2018). Zero waste kerala: An innovative model for waste management in india. Rajagiri Journal of Social Development, 10(2), 161-172. Retrieved from https://search.proquest.com/docview/2241276460?accountid=62689

Opara, J. A., John, A. K., \& Sempewo, J. (2016). Environmental health efficiency and urbanization: The case solid waste management in bor municipality of south sudan. International Journal of Bioinformatics and Biological Sciences, 4(1), 19-33. doi:http://dx.doi.org/10.5958/2321-7111.2016.00004.4

Proshanky, H. M., Ittelson. W. H., and Rivlin. L. G. (1976). Environmental psychology: People and their physical settings, 2nd ed. New York: Holt, Rinehart \& Winston.

Sulistyo, H., \& Cahyono, B. (2010). Model Pengembangan Pasar Tradisional Menuju Pasar Sehat di Kota Semarang. EKOBIS, 11(2), 516-526.

Wahyono, S. (2015). Studi Potensi dan Kualitas Gas dari tempat Pemrosesan Akhir Sampah Kota Probolinggo. Jurnal Teknologi Lingkungan, 1(16), 15-20. Retrieved from http://ejurnal.bppt.go.id/index.php/JTL/ article/view/1608

World Bank 2012. Waste management in china: issues and recommendation. Urban development working papers, East Asia infrastructure department, World Bank working papers No. 9.

Yang, H., Ma, M., Thompson, J. R., \& Flower, R. J. (2018). Waste management, informal recycling, environmental pollution and public health. Journal of Epidemiology and Community Health, 72(3), 237. doi:http://dx.doi.org/10.1136/jech-2016-208597 
Yaqin, A., Laili, S., \& Syauqi, A. (2019). Persepsi Masyarakat terhadap Sanitasi Pasar Tradisional (Pasar Blimbing dan Pasar Mergan) di Kota Malang. BIOSAINTROPIS (BIOSCIENCE-TROPIC), 4(3), 21-25. https://doi.org/10.33474/e-jbst.v4i3.220

Zaman, B., Oktiawan, W., Hadiwidodo, M., \& Sutrisno, E. (2017). Desentralisasi pengolahan limbah padat rumah tangga menggunakan teknologi biodrying. Jurnal Pengelolaan Lingkungan Berkelanjutan, 1(3), 18-24. Retrieved from http://www.bkpsl.org/ojswp/index.php/jplb

https://portal.tasikmalayakota.go.id/sarana-dan-prasarana/tempat-belanja/pasar-tradisional/, diakses tanggal 21 Juli 2019, Pukul 10.00 WIB. 